\title{
Effects of Ultraviolet C Irradiation on Stilbene Biosynthesis in Vitis vinifera L. cv. Cabernet Sauvignon Berry Skins and Calli
}

\author{
A. Xu, J.-C. Zhan*, W.-D. Huang* \\ College of Food Science and Nutritional Engineering, Beijing Key Laboratory of Viticulture and Oenology, China Agricultural \\ University, Beijing, 100083, P.R. China
}

Submitted for publication: December 2014

Accepted for publication: March 2015

Key words: Grape, calli, ultraviolet C, stilbene, flavonoid

Vitis vinifera L. cv. Cabernet Sauvignon berries and calli were irradiated with ultraviolet C (UV-C) to investigate the effects on the biosynthesis of stilbene. The stilbene content in the berry skins was enhanced significantly after 10 min of UV-C irradiation over the $24 \mathrm{~h}$ time course, and the results varied depending on the development stage of the fruit. The maximum production of total stilbene in the berry skins occurred at $12 \mathrm{~h}$ after treatment, with a content of $848.45 \pm 23.53 \mu \mathrm{g} / \mathrm{g}$ fresh weight $(\mathrm{FW})$ at the beginning of véraison, $591.77 \pm 26.90 \mu \mathrm{g} / \mathrm{g} \mathrm{FW}$ at the end of véraison, and $170.71 \pm 6.85 \mu \mathrm{g} / \mathrm{g} \mathrm{FW}$ at the ripening stage. Different UV-C dosages, from 5 to $30 \mathrm{~min}$, induced stilbene accumulation considerably in the calli over the $120 \mathrm{~h}$ experimental period, and $20 \mathrm{~min}$ was the most efficient. The maximum of total stilbene accumulation in the calli was $125.07 \pm 3.01 \mu \mathrm{g} / \mathrm{g} \mathrm{FW}$ at $96 \mathrm{~h}$ after $20 \mathrm{~min}$ irradiation. Total phenolics and total flavonoid content increased after UV-C irradiation in both the berry skins and calli. The relative expression of genes encoding enzymes involved in the branching point of stilbene and flavonoid biosynthesis was up-regulated by UV-C irradiation. The results show that UV-C irradiation significantly promotes stilbene and flavonoid biosynthesis in grape berry skins and calli, and the induction effects depend on fruit development stage and UV-C dosage.

\section{INTRODUCTION}

Phytoalexins are low-molecular-weight antimicrobial compounds that are produced by plants as a response to biotic and abiotic stresses (Jeandet et al., 2014a). Stilbenes are important secondary metabolites of grapevine and act as phytoalexins in defence reactions against attacks by fungi, bacteria, nematodes and herbivores (Jeandet et al., 2002; 2010). Grapes and wines belong to the main food sources of stilbenes (Soleas et al., 1997). Over the past years, much attention has been devoted to stilbenes because of their biological effects on human health, including inhibition of low-density lipoprotein oxidation (Frankel et al., 1995), anticancer action (Jang et al., 1997), cardioprotection (Wallerath et al., 2002) and anti-inflammatory action (Ghanim et al., 2010).

Stilbenes share the basic structure of trans-resveratrol $\left(3,4^{\prime}, 5\right.$,-trihydroxystilbene) and also exist as many resveratrol derivatives, such as piceid (3-O- $\beta$-D-glucoside of resveratrol) (Waterhouse \& Lamuela-Raventos, 1994) and viniferin (cyclic resveratrol oligomer, known as $\varepsilon$-viniferin, $\delta$-viniferin and $\alpha$-viniferin) (Langcake $\&$ Pryce, 1977; Pezet et al., 2003; Vitrac et al., 2005). Cis-form stilbenes can be obtained from trans-form stilbenes through UV-C irradiation (López-Hernández et al., 2007).
Stilbenes are produced by the phenylpropanoid pathway. Phenylalanine ammonia lyase (PAL, EC 4.3.1.24), cinnamate 4-hydroxylase (C4H, EC 1.14.13.11) and 4-coumarate-CoA ligase (4CL, EC 6.2.1.12) catalyse phenylalanine to form 4-coumaroyl-CoA (Dixon \& Paiva, 1995). Stilbene synthase (STS, EC 2.3.1.95) catalyses a condensation reaction of 4-coumaroyl-CoA with three molecules of malonyl-CoA to produce trans-resveratrol (Soleas et al., 1997). Chalcone synthase (CHS, EC 2.3.1.74) is an entrance enzyme of the flavonoid metabolism and utilises the same substrates as STS for the production of chalcone, the precursor of flavonoids (Winkel-Shirley, 2001). 4CL, STS and CHS are the key enzymes that constitute the branching point of stilbene and the flavonoid pathway. The STS gene has been transferred successfully into several plants to obtain stilbene accumulation or increase disease resistance (Delaunois et al., 2009; Jeandet et al., 2013), including tobacco (Hain et al., 1990), oilseed rape (Hüsken et al., 2005) and strawberry (Hanhineva et al., 2009). The STS gene has also been transferred into microorganisms for the production of stilbene (Jeandet et al., 2012).

Stilbenes can be induced by a number of biotic and abiotic factors (Jeandet et al., 2010), such as pathogen attack (Pezet et al., 2004), ultraviolet C (UV-C) irradiation (Langcake \&

*Corresponding author: E-mail address: jczhan@263.net [Tel.: +86-10-62737553; Fax: +86-10-62737553]; E-mail address: huanggwd@263.net [Tel: +86-10-62737024; Fax: +86-10-62737553]

Acknowledgements: This work was supported by the National Natural Science Foundation of China (No. 31471835) and the National "Twelfth Five-Year" Plan for Science \& Technology Support (2012BAD31B07) 
Pryce, 1977), methyl jasmonate elicitation (Belhadj et al., 2006; Jeandet et al., 2014b) and ozone treatment (Zinser et al., 2000). However, UV-C irradiation is mostly absorbed by the atmosphere and is scarcely received by field-grown plants. The application of postharvest UV-C irradiation has been widely used to improve fruit quality. The production of stilbene can be enhanced by UV-C irradiation of Vitis vinifera leaves (Wang et al., 2010), V. vinifera berries (Adrian et al., 2000) and the calli of different genotypes (Liu et al., 2010).

Piceid is the stored and/or transported form of resveratrol (Morales et al., 1998). Piceid accumulates in healthy berries of different genotypes (Gatto et al., 2006), and the content increases after UV-C irradiation (Wang et al., 2013). $\varepsilon$-Viniferin is a resveratrol dehydrodimer that is not widespread in non-infected plants. $\varepsilon$-Viniferin can be stimulated by stresses such as UV-C irradiation (GonzálezBarrio et al., 2006) and fungal inoculation, including with Plasmopara viticola (Pezet et al., 2004) and Aspergillus carbonarius (Bavaresco et al., 2008).

The aim of our present work was to investigate the effects of UV-C irradiation on stilbene biosynthesis in $V$. vinifera L. cv. Cabernet Sauvignon berry skins and calli. Grape berries were irradiated with UV-C at three different stages of development (the beginning of veraison, the end of véraison and the ripening stage) to investigate whether the induction capacity of stilbene production depended on fruit development. We also compared the effects of different UV-C dosages on stilbene accumulation in the grape calli. Stilbene content and relative expression of genes associated with the branching point of stilbene and flavonoid biosynthesis (4CL, STS and CHS) were analysed to study the relationship between stilbene production and the regulation of these genes.

\section{MATERIALS AND METHODS}

\section{Plant material and establishment of calli}

Vitis vinifera L. cv. Cabernet Sauvignon berries were collected at 20,30, 40, 50, 60, 70, 80, 90, 100 and 110 days after full bloom (DAF) from a vineyard in the suburbs of Beijing. Each sample consisted of 50 clusters picked randomly from different plants at the same height and direction. Berries of a similar size without physical injuries or infections were collected. The growth curve of grape berry development was measured by fresh weight. Berries were peeled by hand to obtain the skins. Berry skins were frozen in liquid nitrogen and then stored at $-80^{\circ} \mathrm{C}$ until further analysis.

Grape calli were established from $V$. vinifera L. cv. Cabernet Sauvignon berries at the beginning of véraison, which was the best development stage for the induction of calli on the basis of preliminary experiments (data not shown). For sterilisation, healthy berries from the middle of a cluster were surface-sterilised by $75 \%(\mathrm{v} / \mathrm{v})$ ethanol for $30 \mathrm{~s}$, and then immersed in $2 \%(\mathrm{w} / \mathrm{v})$ sodium hypochlorite with shaking for $15 \mathrm{~min}$. The berries were then rinsed at least five times with sterile distilled water. Sterilised explants were cut into small pieces and cultured on petri dishes containing solid medium. The medium was based on the B5 (Gamborg et al., 1976) macronutrients, micronutrients and vitamins, supplemented with $30 \mathrm{~g} / \mathrm{L}$ sucrose, $250 \mathrm{mg} / \mathrm{L}$ casein hydrolysate, $0.1 \mathrm{mg} / \mathrm{L} \alpha$-naphthylacetic acid (NAA) and $0.2 \mathrm{mg} / \mathrm{L}$ kinetin (KT), adjusted to $\mathrm{pH} 5.9$, and the solid medium was supplemented with $0.3 \%(\mathrm{w} / \mathrm{v})$ phytagel. The explants were maintained at $25 \pm 1^{\circ} \mathrm{C}$ under a $16 / 8 \mathrm{~h}$ light/dark photoperiod $\left(200 \mu \mathrm{E} / \mathrm{m}^{2} / \mathrm{s}\right)$, which were the best conditions for the growth of calli on the basis of preliminary experiments (data not shown). Subcultures of the calli were carried out every four weeks.

\section{UV-C treatments on grape berries and calli}

All of the experiments were performed using three biological replicates. UV-C irradiation of the grape berries was carried out at three different development stages: the beginning of véraison (60 DAF), the end of véraison (70 DAF) and the ripening stage (100 DAF). Grape berries were scattered on white plates and irradiated with a $254 \mathrm{~nm}$ UV-C lamp at $8 \mathrm{~cm}$ distance above (output $10 \mathrm{~W} / \mathrm{m}^{2}$ ) for $10 \mathrm{~min}$ (total exposure dosage was $6 \mathrm{KJ} / \mathrm{m}^{2}$ ). During the irradiation, berries were agitated every 2 min for the purpose of symmetrical irradiation. Berries without UV-C irradiation were used as the control group. Both the UV-C-treated and control berries were incubated in the dark at $25 \pm 1{ }^{\circ} \mathrm{C}$ in the climate incubator with a relative humidity of $70 \%$ until they were sampled. Samples were collected at 0, 0.5, 1, 2, 4, 6, 8, 12 and $24 \mathrm{~h}$ after treatment and peeled by hand immediately. Berry skins were frozen in liquid nitrogen and then stored at $-80^{\circ} \mathrm{C}$ until further analysis.

UV-C irradiation of the calli was carried out at day 18 after subculture. Grape calli were irradiated with a $254 \mathrm{~nm}$ UV-C lamp at $8 \mathrm{~cm}$ distance above (output $10 \mathrm{~W} / \mathrm{m}^{2}$ ) for $5,10,20$ or $30 \mathrm{~min}$ (total exposure dosages were $3,6,12$ or $18 \mathrm{KJ} / \mathrm{m}^{2}$ respectively). During the irradiation, calli were agitated by sterile forceps every $2 \mathrm{~min}$ for the purpose of symmetrical irradiation. Calli at day 18 without UV-C irradiation were used as the control group. Both the UV-Ctreated and control calli were incubated at $25 \pm 1{ }^{\circ} \mathrm{C}$ under a $16 / 8 \mathrm{~h}$ light/dark photoperiod $\left(200 \mu \mathrm{E} / \mathrm{m}^{2} / \mathrm{s}\right)$ until they were sampled. Samples were collected at 0, 6, 12, 24, 36, 48, 72, 96 and $120 \mathrm{~h}$ after treatment, rapidly washed with sterilised distilled water, harvested by vacuum filtration, frozen in liquid nitrogen and stored at $-80^{\circ} \mathrm{C}$ until further analysis.

\section{Extraction and quantification of phenolic compounds} Stilbenes were extracted from $1 \mathrm{~g}$ fresh weight (FW) of berry skins or $1 \mathrm{~g} \mathrm{FW}$ of calli according to the method described by Tassoni et al. (2005). Chromatographic separation was performed on a DIKMA column (Inertsil ODS-3, $250 \times$ $4.6 \mathrm{~mm}, 5 \mu \mathrm{m}$ particle size) protected by a guard column of the same material (DIKMA, Japan). The analysis of stilbenes was carried out on a Waters 2695 HPLC system fitted with a Photodiode Array Detector 2996 (Waters, USA). Stilbenes were quantified as described by Pezet et al. (2003). Trans-resveratrol, trans-piceid and $\varepsilon$-viniferin standards were purchased from Sigma-Aldrich (USA) and dissolved in methanol. Cis-resveratrol and cis-piceid standards were obtained by UV-C irradiation at a distance of $8 \mathrm{~cm}$ above (output $10 \mathrm{~W} / \mathrm{m}^{2}$ ) for $30 \mathrm{~min}$ (total exposure dosage was $18 \mathrm{KJ} / \mathrm{m}^{2}$ ) on the mixed solution of trans-resveratrol and trans-piceid standards. The conversion coefficients were $37.1 \%$ for trans-resveratrol and $42.6 \%$ for trans-piceid. The total stilbene content indicates the sum of trans-piceid, 
cis-piceid, trans-resveratrol, cis-resveratrol and $\varepsilon$-viniferin contents.

Total phenolics were extracted from 1 g FW of berry skins or $1 \mathrm{~g} \mathrm{FW}$ of calli according to the method described by Pastrana-Bonilla et al. (2003) and measured according to the Folin-Ciocalteu reagent method. The results were expressed as milligrams of gallic acid per gram FW. The total flavonoid content was measured according to Wolfe et al. (2003). The results were expressed as milligrams of catechin per gram FW. All of the measurements were performed in triplicate.

RNA isolation, cDNA preparation and qRT-PCR analysis The total RNA of the grape berry skins or calli was isolated using Column Plant RNA ${ }_{\text {OUT }} 2.0$ Kit (Tiandz, China), and cDNA was prepared using a Thermo Scientific RevertAid First Strand cDNA Synthesis Kit (Thermo Fischer Scientific, USA) according to the manufacturer's protocol. The amplification of Actinl was used as the internal reference gene to normalise the expression of the selected genes. The STS, CHS and Actin1 primer sequences were designed based on $V$. vinifera nucleotide sequences deposited in GenBank, using Primer Premier 5 and Oligo 6, and the $4 C L$ primers have been described by Wang et al. (2013). All primer pairs are given in Table 1.

Quantitative real-time polymer chain reaction (qRTPCR) was performed using a CFX96 Touch $^{\mathrm{TM}}$ Real-Time PCR Detection System (Bio-Rad, USA). Each reaction was performed in triplicate with a reaction volume of $20 \mu \mathrm{L}$, containing $1 \mu \mathrm{L}$ of template (50 ng cDNA), $1 \mu \mathrm{L}$ of forward primer (400 nM, final concentration), $1 \mu \mathrm{L}$ of reverse primer (400 nM, final concentration), $10 \mu \mathrm{L} \mathrm{iTaq}^{\mathrm{TM}}$ Universal SYBR Green Supermix (Bio-Rad, UK) and $7 \mu \mathrm{L}$ of nuclease-free sterile water (Amresco, USA). Cycling parameters were $94^{\circ} \mathrm{C}$ for $5 \mathrm{~min}$, followed by 40 cycles of $94^{\circ} \mathrm{C}$ for $5 \mathrm{~s}$ and $60^{\circ} \mathrm{C}$ for $30 \mathrm{~s}$. The melting curve analysis was performed from 65 to $95^{\circ} \mathrm{C}$. Data were analysed using Bio-Rad CFX Manager Software 1.6. Relative mRNA ratios were calculated with the $2^{-\triangle \Delta C T}$ method (Livak \& Schmittgen, 2001), using Actin1 as the standard control. For the experiments on the grapes throughout berry development, berry skins at 20 DAF were considered as the reference sample. For the UV-C treatments, control berry skins or control calli (at time zero) were considered as the reference sample. For each gene, the reference sample was defined as expression $=1$, and results were expressed as the fold changes compared to the reference sample.

\section{Statistical analysis}

Graphs of the experimental data were developed using OriginPro 8.1 (OriginLab, USA). The experimental data were means \pm standard error (SE) of three replicates, and the statistical analysis was performed using SPSS 20 (SPSS, USA). The significant difference was tested using Student's $t$-test (at $p<0.05$ ) and Duncan's multiple range test (at $p<0.05)$.

\section{RESULTS AND DISCUSSION}

\section{Changes in stilbene biosynthesis in grape berry skins during fruit development}

The changes in the fresh weight of $V$. vinifera $\mathrm{L}$. cv. Cabernet
Sauvignon berries are shown in Fig. 1A. The growth pattern of developing berries followed a double sigmoid curve. The whole developing curve could be divided into three phases: the rapid growth phase (20 to $40 \mathrm{DAF}$ ), the lag growth phase (40 to $60 \mathrm{DAF}$ ) and the second rapid growth phase (60 to 100 DAF). Then berries were in the over-ripe stage (after $100 \mathrm{DAF}$ ). The results suggest that véraison took place at 60 to $70 \mathrm{DAF}$, when the berries started to turn red and soft. Grape clusters collected at 60 DAF contained both coloured and green berries, and berries collected at 70 DAF were fully coloured. We collected berries at $60 \mathrm{DAF}$ (the beginning of véraison), $70 \mathrm{DAF}$ (the end of véraison) and $100 \mathrm{DAF}$ (the ripening stage) for UV-C elicitation.

The HPLC method was used to determine stilbene composition and content in the grape berry skins. The distribution of resveratrol in $V$. vinifera grapevine is organ specific and tissue specific (Wang et al., 2010). Stilbenes accumulate more in the skin than in the flesh during all stages of grape development (Jeandet et al., 1991), so only stilbenes in the berry skins were analysed. Only trans-piceid and trans-resveratrol were detected during the fruit development stages. The trans-piceid content (Fig. 1B) was low in the early stages and increased around véraison, reaching a maximum of $55.02 \pm 1.50 \mu \mathrm{g} / \mathrm{g} \mathrm{FW}$ at $100 \mathrm{DAF}$. The transresveratrol content (Fig. 1C) decreased in the early stages to a minimum at $50 \mathrm{DAF}$, and then increased after véraison to a maximum of $16.04 \pm 0.69 \mu \mathrm{g} / \mathrm{g} \mathrm{FW}$ at $100 \mathrm{DAF}$. Both the trans-piceid and trans-resveratrol contents declined at the overripe stage (110 DAF). Total stilbene content (Fig. 1D) increased to a maximum of $71.06 \pm 1.87 \mu \mathrm{g} / \mathrm{g} \mathrm{FW}$ at 100 DAF and declined at 110 DAF. The stilbene content in grape berries depends on the grape cultivar (Douillet-Breuil et al., 1999; Li et al., 2006; Guerrero et al., 2010), and stilbene biosynthesis is related to the stage of development (Versari et al. 2001; Fornara et al., 2008). Our results show that the stilbene content in berry skins increased from véraison to the ripening stage, in agreement with the findings of Gatto et al. (2008) and Dai et al. (2012). The total phenolic content (Fig. 1E) showed high levels at 20 to $30 \mathrm{DAF}$, but decreased rapidly to a minimum at $50 \mathrm{DAF}$, and then increased rapidly at véraison and finally remained constant until the ripening stage $(92.85 \pm 3.21 \mathrm{mg}$ gallic acid/g FW at $100 \mathrm{DAF})$. The total flavonoid content (Fig. 1F) decreased in the early stages and increased gradually from véraison to the ripening stage, with a maximum of $28.89 \pm 0.72 \mathrm{mg}$ catechin $/ \mathrm{g} F W$ at the overripe stage (110 DAF).

The relative expression of the key genes associated with the branching point of stilbene and flavonoid biosynthesis ( $4 C L, S T S$ and $C H S$ ) is shown in Fig. 2. The expression of $4 C L$ (Fig. 2A) decreased from 30 to $60 \mathrm{DAF}$ and reached a peak at $70 \mathrm{DAF}$, followed by a rapid decline to low levels at the ripening stage. The expression of STS (Fig. 2B) reached two peaks at 30 and $60 \mathrm{DAF}$, and then decreased gradually to low levels until the ripening stage. The expression of $\mathrm{CHS}$ (Fig. 2C) increased drastically at 60 DAF to a maximum at $70 \mathrm{DAF}$, and then declined to low levels, followed by another peak at 100 DAF. Genes encoding enzymes involved in the anthocyanin biosynthetic pathway were demonstrated to be ripening-specific regulatory genes (Waters et al., 2005). As described by Boss et al. (1996), CHS expression levels were 
high at the green stage, followed by a peak at véraison, and then declined to low levels at the ripening stage. Our results were in agreement with those in the literature.

Effect of UV-C irradiation on stilbene biosynthesis in grape berry skins at three development stages

Postharvest UV-C irradiation has been considered to be an effective way to achieve stilbene and flavonoid accumulation in grapes. Cantos et al. (2000) tested the effects of UV-B and
UV-C on stilbene production in cv. Napoleon grape skins and found that UV-C irradiation produced a greater increase in trans-resveratrol than UV-B irradiation. Stilbene production in the grape berry skins at three stages of development over the $24 \mathrm{~h}$ time course after UV-C treatment is shown in Fig. 3. Trans-piceid and trans-resveratrol were observed in both the UV-C-treated and control berry skins, and the stilbene content in the control group remained low and constant during the experimental period. $\varepsilon$-Viniferin was not detected

TABLE 1

Primers used for qRT-PCR

\begin{tabular}{lll}
\hline Gene & Accession number & Primers (5' 3’') $^{\prime}$ \\
\hline Actin1 & AY680701 & Forward: CTACTGCTGAACGGGAAAT \\
& & Reverse: ACTTCTGGACAACGGAATC \\
$4 C L$ & XM_002274958 & Forward: CGAAGAACCCGATGGTGGAGA \\
& & Reverse: CACGAGCCGGACTTAGTAGGA \\
STS & EU156062 & Forward: TGTTTGACTCAGGCTTTTG \\
& & Reverse: CCTTATGGGATTTCTTTCTC \\
CHS & X75969 & Forward: CGATAGGCATCAGCGACT \\
& & Reverse: TTTTCCTCATTTCGTCCAG \\
\hline
\end{tabular}
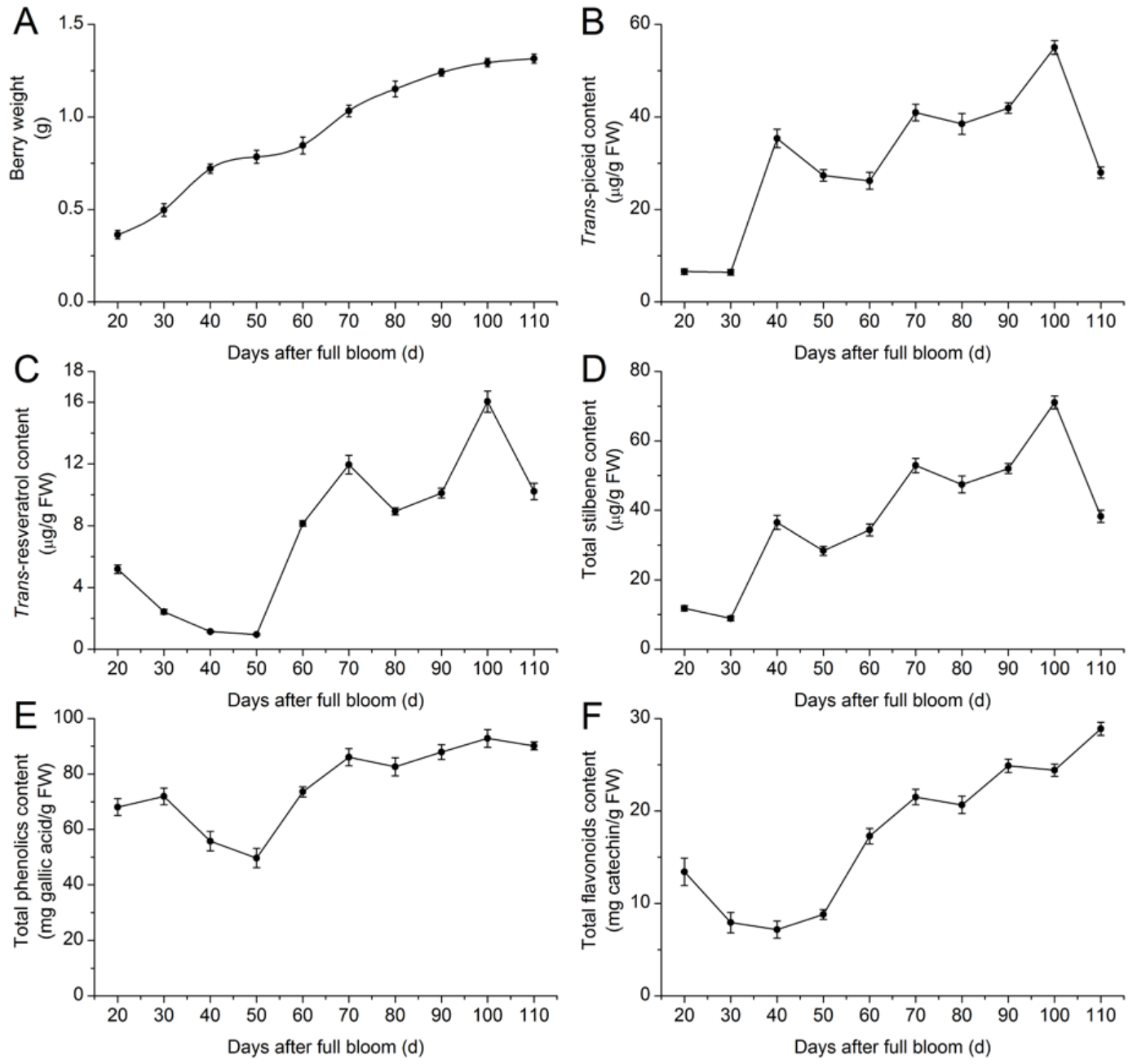

FIGURE 1

Changes in fresh weight (A) of Vitis vinifera L. cv. Cabernet Sauvignon berries and changes in trans-piceid (B), trans-resveratrol $(\mathrm{C})$, total stilbene (D), total phenolic (E) and total flavonoid (F) contents in berry skins at different fruit development stages. Total stilbene content indicates the sum of $(B)$ and $(C)$. Values are means \pm SE $(n=3)$. 

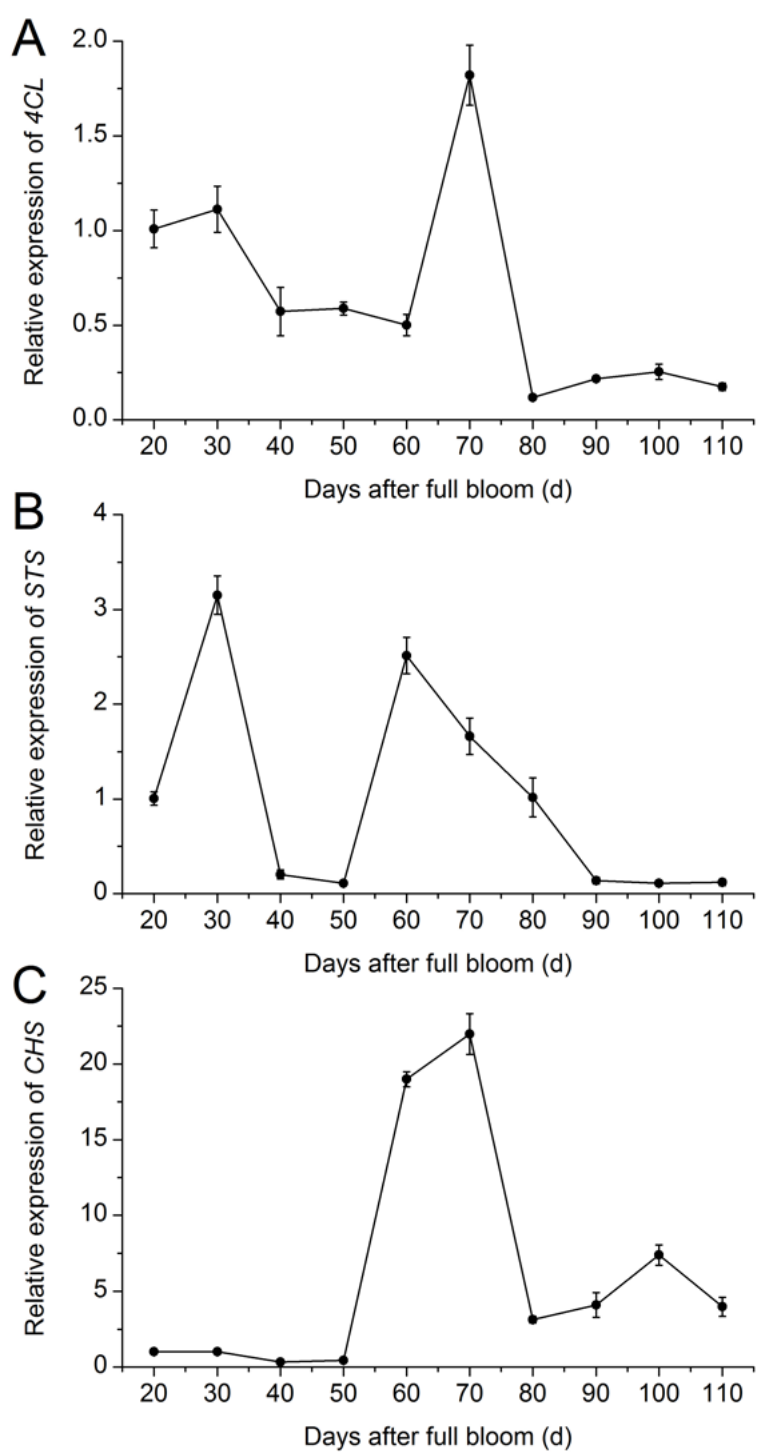

FIGURE 2

Changes in relative expression of $4 C L$ (A), STS (B) and CHS (C) in Vitis vinifera L. cv. Cabernet Sauvignon berry skins at different fruit development stages. Values are means $\pm \mathrm{SE}$

$$
(n=3) \text {. }
$$

in the control berry skins, but it appeared at $12 \mathrm{~h}$ and $24 \mathrm{~h}$ after UV-C irradiation at all development stages.

At the beginning of veraison (60 DAF) (Fig. 3A), the trans-piceid content was induced to a peak at $0.5 \mathrm{~h}$ and then declined, after which it increased rapidly to a maximum of $40.61 \pm 1.00 \mu \mathrm{g} / \mathrm{g} \mathrm{FW}$ at $4 \mathrm{~h}$. An increasing trend of transresveratrol content was observed in the experimental period, up to a maximum of $800.56 \pm 21.92 \mu \mathrm{g} / \mathrm{g} \mathrm{FW}$ at $12 \mathrm{~h}$, which was a 98.71-fold increase compared to the $12 \mathrm{~h}$ control. $\varepsilon$-Viniferin was undetectable during the first $8 \mathrm{~h}$, and its content increased slightly from $11.97 \pm 0.51 \mu \mathrm{g} / \mathrm{g} \mathrm{FW}$ at $12 \mathrm{~h}$ to $15.94 \pm 0.66 \mu \mathrm{g} / \mathrm{g} \mathrm{FW}$ at $24 \mathrm{~h}$. The total stilbene content increased along the time course to a maximum of $848.45 \pm$ $23.53 \mu \mathrm{g} / \mathrm{g} \mathrm{FW}$ at $12 \mathrm{~h}$, which was a 23.27 -fold increase with respect to the control group.

At the end of veraison (70 DAF) (Fig. 3B), the transpiceid content reached a peak of $60.85 \pm 1.29 \mu \mathrm{g} / \mathrm{g} \mathrm{FW}$ at $4 \mathrm{~h}$. The trans-resveratrol content was promoted progressively along the time course to a maximum of $533.98 \pm 25.40 \mu \mathrm{g} / \mathrm{g}$ FW, with a 42.08-fold increase from the $12 \mathrm{~h}$ control. $\varepsilon$-Viniferin was also not observed until $12 \mathrm{~h}(9.32 \pm 0.35 \mu \mathrm{g} / \mathrm{g}$ FW), and its content increased to $14.27 \pm 0.49 \mu \mathrm{g} / \mathrm{g} \mathrm{FW}$ at $24 \mathrm{~h}$. The total stilbene content reached a maximum of $591.77 \pm 26.90 \mu \mathrm{g} / \mathrm{g} \mathrm{FW}$ at $12 \mathrm{~h}$, which was 10.91 -fold that of the control group.

At the ripening stage (100 DAF) (Fig. 3C), the transpiceid content peaked at $0.5 \mathrm{~h}$ with a content of 90.90 $\pm 2.17 \mu \mathrm{g} / \mathrm{g} \mathrm{FW}$, and then decreased gradually to $70.95 \pm$ $2.22 \mu \mathrm{g} / \mathrm{g} \mathrm{FW}$ at $24 \mathrm{~h}$. Trans-resveratrol was stimulated significantly to the highest content of $88.03 \pm 4.64 \mu \mathrm{g} / \mathrm{g}$ FW at $12 \mathrm{~h}$, which was a 5.60-fold increase with respect to the control group. $\varepsilon$-Viniferin was first detected at $12 \mathrm{~h}$ post-treatment with a content of $6.84 \pm 0.37 \mu \mathrm{g} / \mathrm{g} \mathrm{FW}$, and decreased slightly to $6.56 \pm 0.22 \mu \mathrm{g} / \mathrm{g} \mathrm{FW}$ at $24 \mathrm{~h}$. Total stilbene content was enhanced along the whole time course, and the maximum was $170.71 \pm 6.85 \mu \mathrm{g} / \mathrm{g} \mathrm{FW}$ at $12 \mathrm{~h}$, which was a 2.35 -fold increase compared to the control group.

In our present work, UV-C irradiation significantly enhanced the stilbene content in the berry skins of the three development stages. Trans-piceid was the main stilbene in the control berry skins, but the trans-resveratrol content increased drastically at $12 \mathrm{~h}$ after UV-C irradiation and became the predominant stilbene. The best induction capacity of stilbene production was obtained at the beginning of véraison (60 DAF), followed by the end of véraison (70 $\mathrm{DAF})$, and then the ripening stage (100 DAF).

The total phenolic and total flavonoid contents in the grape berry skins over the $24 \mathrm{~h}$ time course after UV-C irradiation are shown in Fig. 4. At the beginning of véraison (60 DAF) (Fig. 4A), the total phenolic content increased gradually to a maximum of $105.41 \pm 1.62 \mathrm{mg}$ gallic acid/g FW at $12 \mathrm{~h}$. The total flavonoid contents showed a rapid accumulation to a peak of $31.05 \pm 0.91 \mathrm{mg}$ catechin $/ \mathrm{g} \mathrm{FW}$ at $6 \mathrm{~h}$. At the end of véraison (70 DAF) (Fig. 4B), total phenolics accumulated to a maximum content of $143.54 \pm 4.98 \mathrm{mg}$ gallic acid $/ \mathrm{g} \mathrm{FW}$ at $8 \mathrm{~h}$. The content of total flavonoids reached a maximum of $45.61 \pm 1.35 \mathrm{mg}$ catechin/g FW at $8 \mathrm{~h}$. At the ripening stage (100 DAF) (Fig. 4C), the total phenolic content was induced to a peak at $6 \mathrm{~h}(120.04 \pm 2.50 \mathrm{mg}$ gallic acid/g FW) and then decreased. The total flavonoid content increased during the time course, with a peak of $38.84 \pm 1.11 \mathrm{mg}$ catechin $/ \mathrm{g} \mathrm{FW}$ at $8 \mathrm{~h}$, and then declined. Both total phenolic and total flavonoid contents were significantly enhanced after UV-C irradiation. These results agree with the findings of Crupi et al. (2013), who reported that postharvest UV-C exposure induced both stilbene and flavonoid biosynthesis in $V$. vinifera berry skins.

As shown in Fig. 5, the expression levels of 4CL, STS, and $C H S$ were significantly up-regulated by UV-C irradiation at all three development stages. At the beginning of véraison (60 DAF) (Fig. 5A), the expression of $4 C L$ peaked at $8 \mathrm{~h}$, with a 2.17-fold increase compared to the control group. The expression of STS accumulated slightly from the beginning of the treatment and increased rapidly at $6 \mathrm{~h}$ to a maximum at $8 \mathrm{~h}$, which was 78.96-fold higher than the control group, and then decreased. The expression of CHS was induced to a peak at $4 \mathrm{~h}$, with a 1.97-fold increase compared to the control group, and then declined to the control levels.

At the end of véraison (70 DAF) (Fig. 5B), the expression 

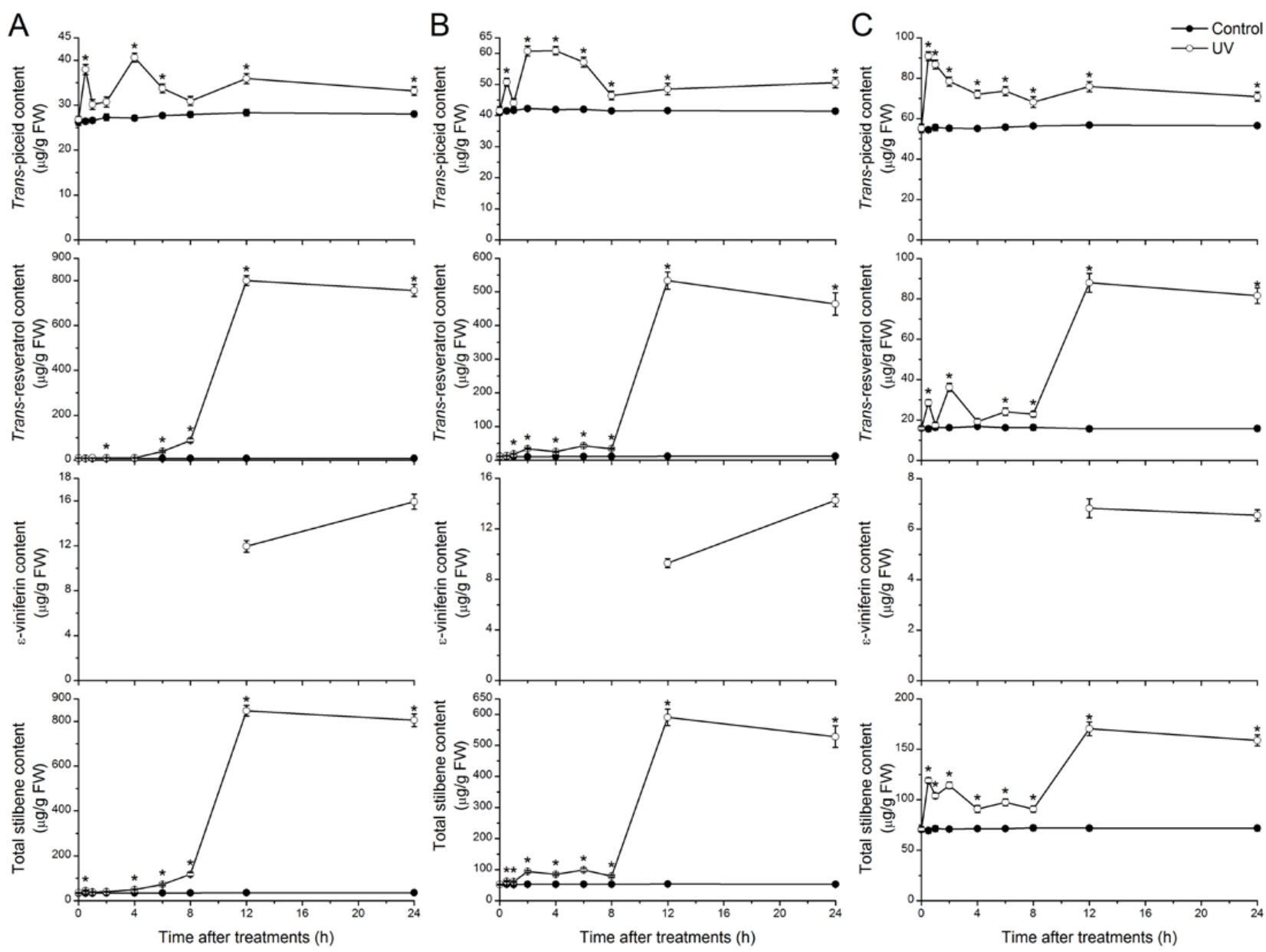

FIGURE 3

Changes in stilbene content in Vitis vinifera L. cv. Cabernet Sauvignon berry skins induced by UV-C irradiation at three development stages. Grape berries at 60 DAF (A), 70 DAF (B) and 100 DAF (C) were irradiated by UV-C (output 10 W/m²) for $10 \mathrm{~min}$ (total exposure dosage was $6 \mathrm{KJ} / \mathrm{m}^{2}$ ) and collected over a $24 \mathrm{~h}$ time course. Berries without UV-C irradiation were used as the control group. Total stilbene content indicates the sum of the trans-piceid, trans-resveratrol and $\varepsilon$-viniferin contents. Values are means $\pm \mathrm{SE}(\mathrm{n}=3)$. $\left(^{*}\right)$ indicates the statistically significant difference (Student's $t$-test, $\left.p<0.05\right)$ between the UVC-treated and control groups at each time point.
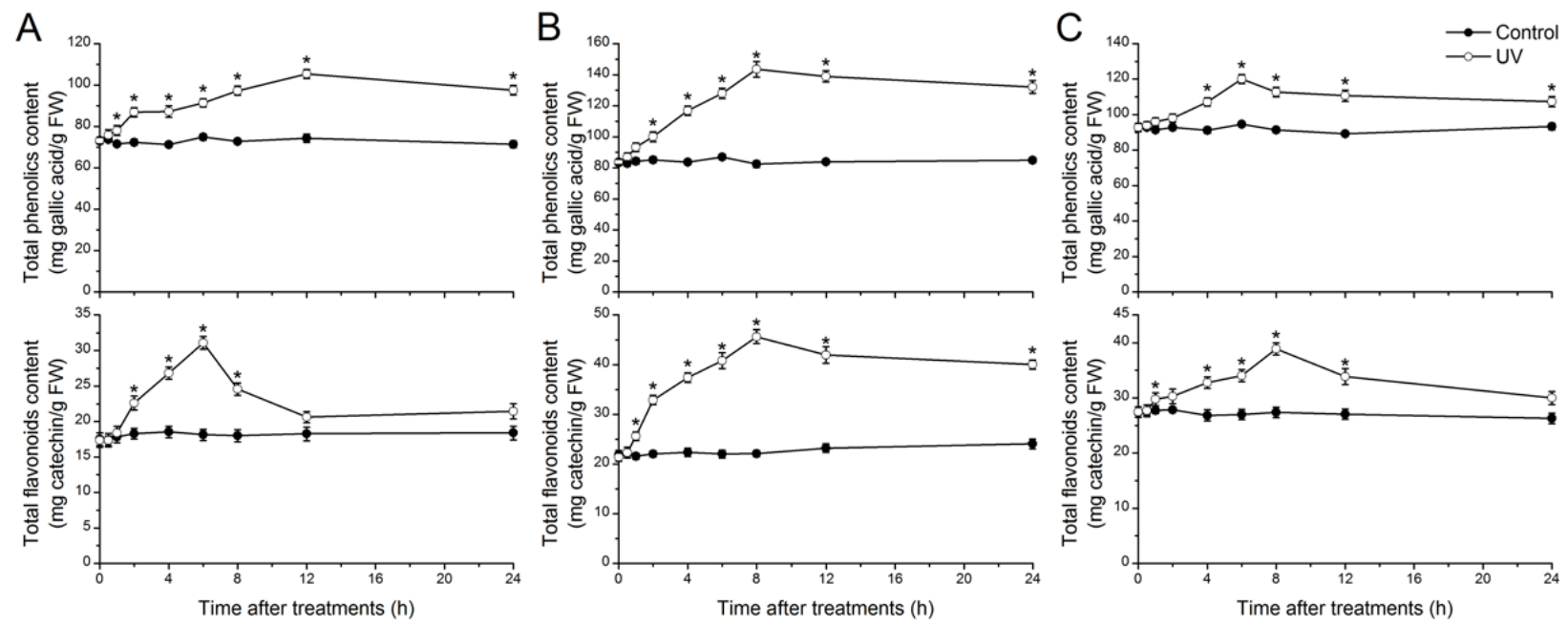

FIGURE 4

Changes in total phenolic and total flavonoid contents in Vitis vinifera L. cv. Cabernet Sauvignon berry skins induced by UV-C irradiation at three development stages. Grape berries at 60 DAF (A), 70 DAF (B) and 100 DAF (C) were irradiated by UV-C (output $10 \mathrm{~W} / \mathrm{m}^{2}$ ) for $10 \mathrm{~min}$ (total exposure dosage was $6 \mathrm{KJ} / \mathrm{m}^{2}$ ) and collected over a $24 \mathrm{~h}$ time course. Berries without UV-C irradiation were used as the control group. Values are means $\pm \operatorname{SE}(\mathrm{n}=3)$. (*) indicates the statistically significant difference

(Student's $t$-test, $p<0.05$ ) between the UV-C-treated and control groups at each time point. 
of $4 C L$ increased 5.34 times to a peak at $12 \mathrm{~h}$. The expression of STS was induced to two peaks at $6 \mathrm{~h}$ and $12 \mathrm{~h}$ postelicitation (35.78- and 31.11-fold higher than the control group), and then declined. The maximum $C H S$ expression levels showed a 4.64-fold increase from the control group at $24 \mathrm{~h}$.

At the ripening stage (100 DAF) (Fig. 5C), the expression of $4 C L$ reached a maximum at $4 \mathrm{~h}$, which was 2.32-fold higher than the $4 \mathrm{~h}$ control. The expression of STS increased drastically to a peak at $12 \mathrm{~h}$, with an 11.25-fold increase compared to the control group. The expression of CHS increased from the early experimental period, reaching the peak at $1 \mathrm{~h}$, which was a 1.61-fold increase with respect to the control group, and then declined to the control levels.

$4 \mathrm{CL}$, STS and CHS are the key enzymes involved in the branching point of the stilbene and flavonoid pathway. Wang et al. (2013) reported that expression levels of $P A L$, $C 4 H, 4 C L$ and STS were up-regulated after UV-C irradiation, and the peak of expression of the related genes appeared earlier than the increase in stilbene content. UV-C irradiation induced the flavonoid pathway in Petroselinum crispum cells, and the expression of CHS increased during the time course after UV treatment (Logemann et al., 2000). In this study, all the genes involved in this branching point were upregulated at transcript levels, and the production of stilbene and flavonoid was consistent with the gene expression. The results suggest that UV-C enhanced the production of stilbene in $V$. vinifera berry skins without a negative effect on the flavonoid content, which is an important parameter of wine quality. UV-C strongly induced stilbene synthesis at the beginning of véraison, and flavonoid synthesis was highly promoted at the end of veraison. The induction capacity of both stilbene and flavonoid synthesis was weak at the ripening stage.

\section{Effect of UV-C irradiation on stilbene biosynthesis in grape calli}

The changes in stilbene content in $V$. vinifera $\mathrm{L}$. cv. Cabernet Sauvignon calli at different time points over the $120 \mathrm{~h}$ period after UV-C irradiation are shown in Fig. 6. Trans-piceid, cispiceid and trans-resveratrol were detected in all the samples, while $c i s$-resveratrol was not observed. The stilbene content in the control calli remained low and constant along the time course. UV-C irradiation for durations of 5 to $30 \mathrm{~min}$ significantly promoted stilbene accumulation. The transpiceid content (Fig. 6A) increased rapidly at $36 \mathrm{~h}$ to a peak at $48 \mathrm{~h}$, then declined to some extent at $72 \mathrm{~h}$ and reached a maximum at $96 \mathrm{~h}$. The cis-piceid content (Fig. 6B) increased gradually during the experimental period, and the content was higher when the UV-C dosage increased. The transresveratrol content (Fig. 6C) increased from $6 \mathrm{~h}$ to a maximum at $36 \mathrm{~h}$, and then declined after $48 \mathrm{~h}$ and remained constant until $120 \mathrm{~h}$. The $\varepsilon$-viniferin content (Fig. 6D) was absent from the control group, but it was detectable from $72 \mathrm{~h}$ after $5 \mathrm{~min}$ irradiation, $48 \mathrm{~h}$ after 10 and $20 \mathrm{~min}$ irradiation, and $36 \mathrm{~h}$ after $30 \mathrm{~min}$ irradiation. Total stilbene content (Fig. 6E) reached a maximum at $96 \mathrm{~h}$, with contents of $88.75 \pm 3.84$, $92.21 \pm 2.36,125.07 \pm 3.01$ and $125.34 \pm 3.94 \mu \mathrm{g} / \mathrm{g} \mathrm{FW}$ after
A

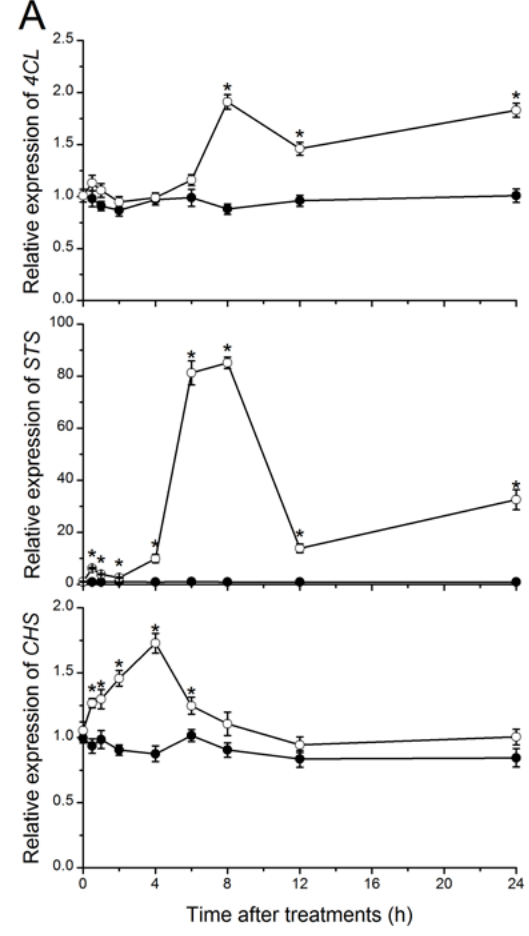

$\mathrm{B}$

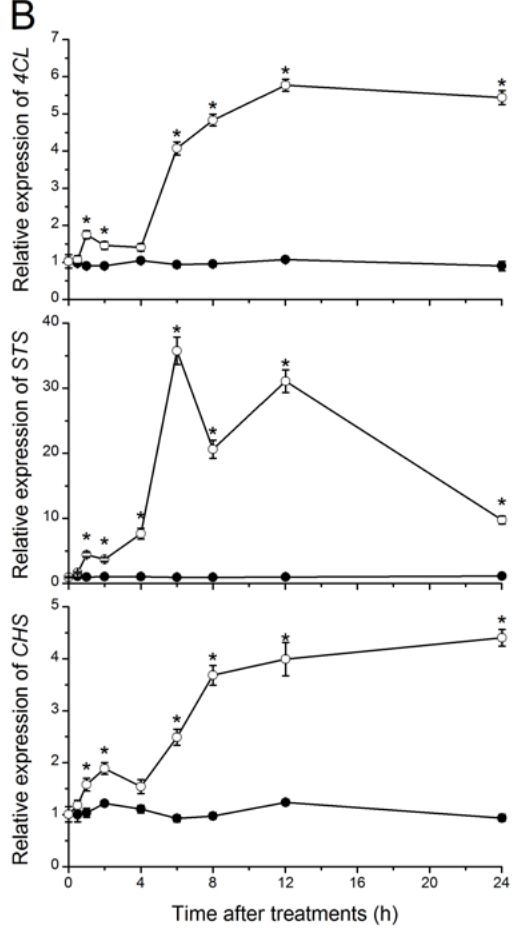

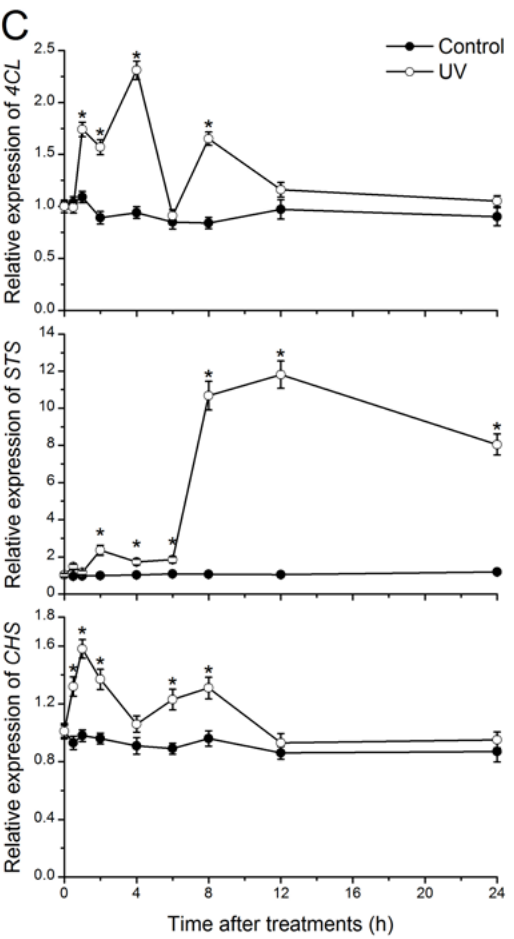

FIGURE 5

Changes in relative expression of $4 C L, S T S$ and CHS in Vitis vinifera L. cv. Cabernet Sauvignon berry skins at 60 DAF (A), 70 DAF (B) and 100 DAF (C) induced by UV-C irradiation at three development stages. Grape berries were irradiated by UV-C (output $10 \mathrm{~W} / \mathrm{m}^{2}$ ) for $10 \mathrm{~min}$ (total exposure dosage was $6 \mathrm{KJ} / \mathrm{m}^{2}$ ) and collected over a $24 \mathrm{~h}$ time course. Berries without UV-C irradiation were used as the control group. Values are means $\pm \mathrm{SE}(\mathrm{n}=3)$. $\left(^{*}\right)$ indicates the statistically significant difference

(Student's $t$-test, $p<0.05$ ) between the UV-C-treated and control groups at each time point. 
$5,10,20$ and $30 \mathrm{~min}$ irradiation respectively, which was a 3.74-, 3.89-, 5.28- and 5.29-fold increase compared to the control group. The total stilbene content after 20 and $30 \mathrm{~min}$ irradiation showed no significant differences, and they were higher than that of 5 and $10 \mathrm{~min}$ irradiation, as well as of the control group. Liu et al. (2010) reported that longer periods of UV-C irradiation reduced the growth index of grape calli. Therefore, $20 \mathrm{~min}$ was chosen as the optimal irradiation time of UV-C for further analysis. Jeandet et al. (1992) reported that stilbene production by in vitro-grown Vitis vinifera leaves in response to UV-exposure depended on the energy fluence rate and time of exposure. In this study, we tested the effect of different UV-C dosages on stilbene production in $V$. vinifera calli and found that longer exposure time yielded more stilbene. Similarly, Liu et al. (2010) reported that UV-C irradiation induced the accumulation of trans-piceid and trans-resveratrol in grape calli, and the effects depended on genotypes, tissue types and UV-C dosages. Our results show that trans-resveratrol displayed a transient accumulation to a peak at $36 \mathrm{~h}$ and declined after $48 \mathrm{~h}$. Since piceid is the stored and/or transported form of resveratrol in response to stress (Morales et al., 1998), we proposed that resveratrol might be utilised to form piceid and other derivatives like $\varepsilon$-viniferin.

The total phenolic and total flavonoid contents in the calli after 20 min UV-C irradiation are shown in Fig. 7. In UV-C-treated calli, the total phenolic content (Fig. 7A) increased gradually to a maximum of $53.49 \pm 1.24 \mathrm{mg}$ gallic $\mathrm{acid} / \mathrm{g} \mathrm{FW}$ at $48 \mathrm{~h}$, which was a 2.42-fold increase compared to the control group. The total flavonoid content (Fig. 7B) accumulated to a maximum of $5.97 \pm 0.25 \mathrm{mg}$ catechin $/ \mathrm{g} \mathrm{FW}$ at $36 \mathrm{~h}$ after UV-C irradiation, which was 2.90 -fold higher compared to the control group.

The relative expression of $4 C L, S T S$ and $C H S$ in calli after 20 min UV-C irradiation is shown in Fig. 8. The expression of $4 C L$ (Fig. 8A) showed a peak at $6 \mathrm{~h}$ and decreased to the control level at $12 \mathrm{~h}$, and then increased rapidly to a maximum at $48 \mathrm{~h}$, which was a 2.92 -fold increase from the control group. The expression of STS (Fig. 8B) showed an increasing trend towards the maximal level at $24 \mathrm{~h}$, which
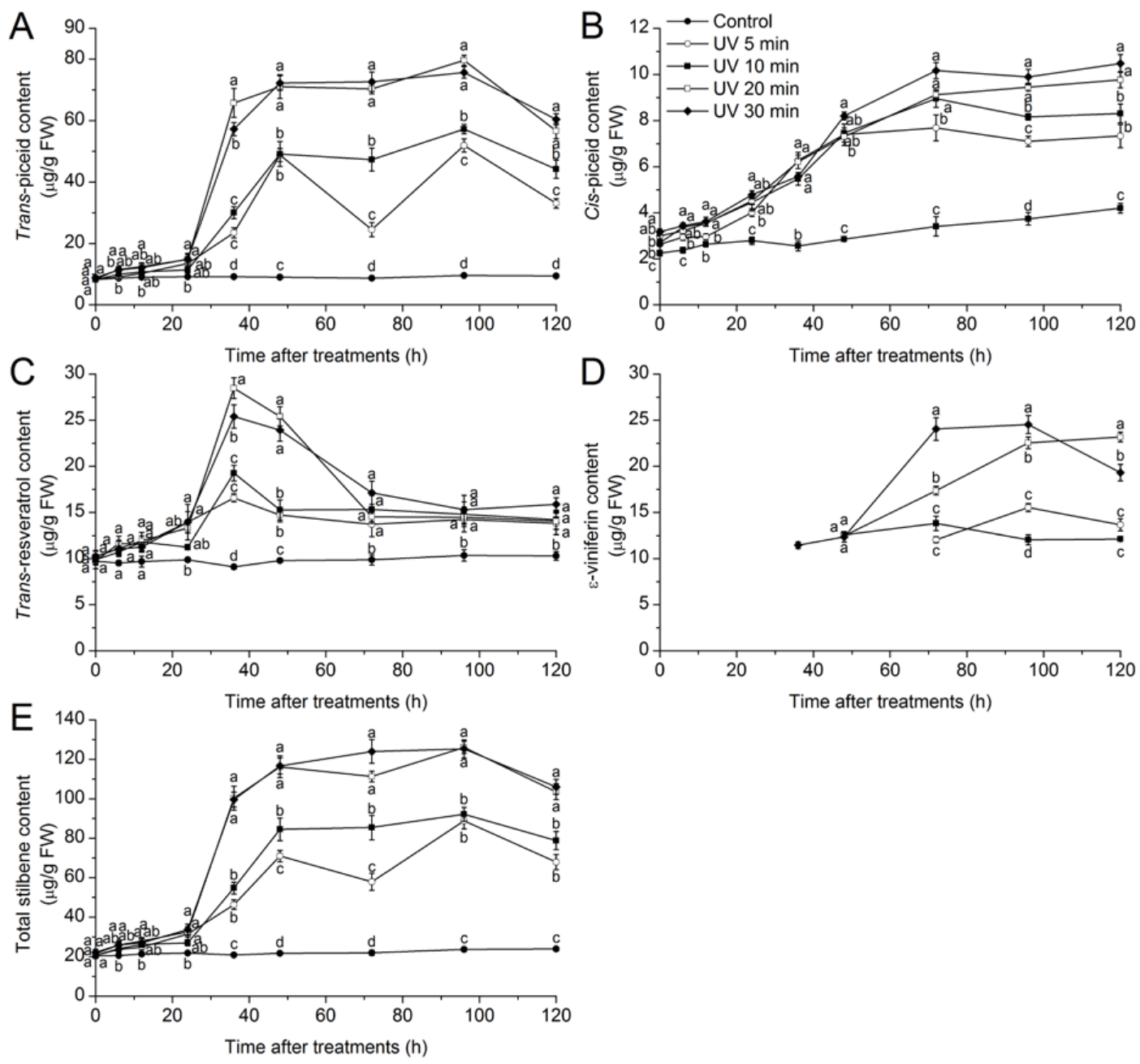

FIGURE 6

Changes in stilbene content in Vitis vinifera L. cv. Cabernet Sauvignon calli induced by UV-C irradiation over a $120 \mathrm{~h}$ time course. Calli at day 18 were irradiated by UV-C (output $10 \mathrm{~W} / \mathrm{m}^{2}$ ) for 5, 10, 20 and 30 min (total exposure dosages were 3, 6, 12 and $18 \mathrm{KJ} / \mathrm{m}^{2}$ ). Calli without UV-C irradiation were used as the control group. The total stilbene content (E) indicates the sum of the trans-piceid (A), cis-piceid (B), trans-resveratrol (C) and $\varepsilon$-viniferin (D) contents. Values are means $\pm \mathrm{SE}(\mathrm{n}=3$ ). Different letters indicate the statistically significant differences (Duncan's multiple range test, $p<0.05$ ) among treatments at each time point. 

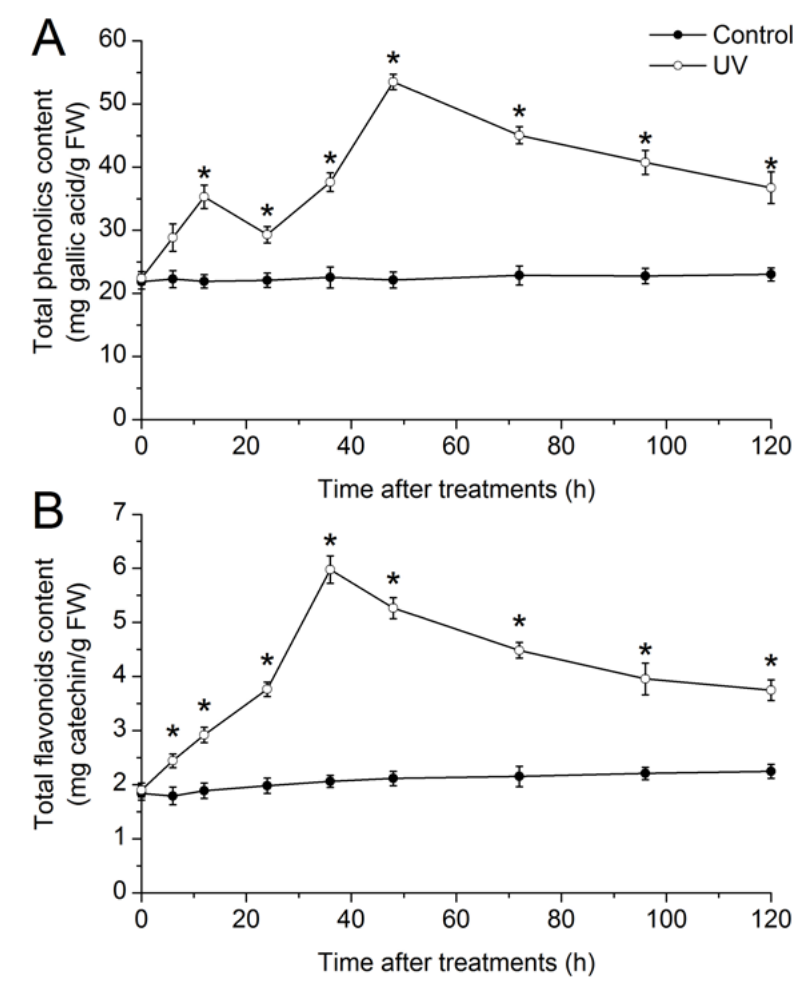

FIGURE 7

Changes in total phenolic (A) and total flavonoid (B) contents in Vitis vinifera L. cv. Cabernet Sauvignon calli induced by UV-C irradiation over a $120 \mathrm{~h}$ time course. Calli at day 18 were irradiated by UV-C (output $10 \mathrm{~W} / \mathrm{m}^{2}$ ) for 20 $\min$ (total exposure dosage was $12 \mathrm{KJ} / \mathrm{m}^{2}$ ). Calli without $\mathrm{UV}-\mathrm{C}$ irradiation were used as the control group. Values are means $\pm \operatorname{SE}(n=3) .(*)$ indicates the statistically significant difference (Student's $t$-test, $p<0.05$ ) between the UV-Ctreated and control groups at each time point.

was 81.58 -fold higher than that of the control group, and then decreased gradually during the rest of the time course. The expression of CHS (Fig. 8C) reached a peak at $24 \mathrm{~h}$, which was 4.51-fold higher compared with the control group, and then declined. The changes of the expression levels of $4 C L$, STS and CHS in the calli after UV-C irradiation were similar to those observed in the berry skins.

Postharvest UV-C irradiation can be used as an efficient method to produce stilbene-enriched wines. Cantos et al. (2003) reported that there was no significant difference in sensory and oenological parameters between stilbeneenriched grapes treated by UV-C and control grapes. The UV-C enhanced the stilbene content of white grapes without affecting the sensory properties of the corresponding juice (González-Barrio et al., 2009).

\section{CONCLUSIONS}

In the present work we demonstrated the effects of UV-C irradiation on stilbene biosynthesis in $V$. vinifera L. cv. Cabernet Sauvignon berry skins and calli. UV-C highly promoted stilbene and flavonoid production, and the induction capacity depended on the stage of fruit development and UV-C dosages. The strongest induction of stilbene production in berry skins occurred at the beginning
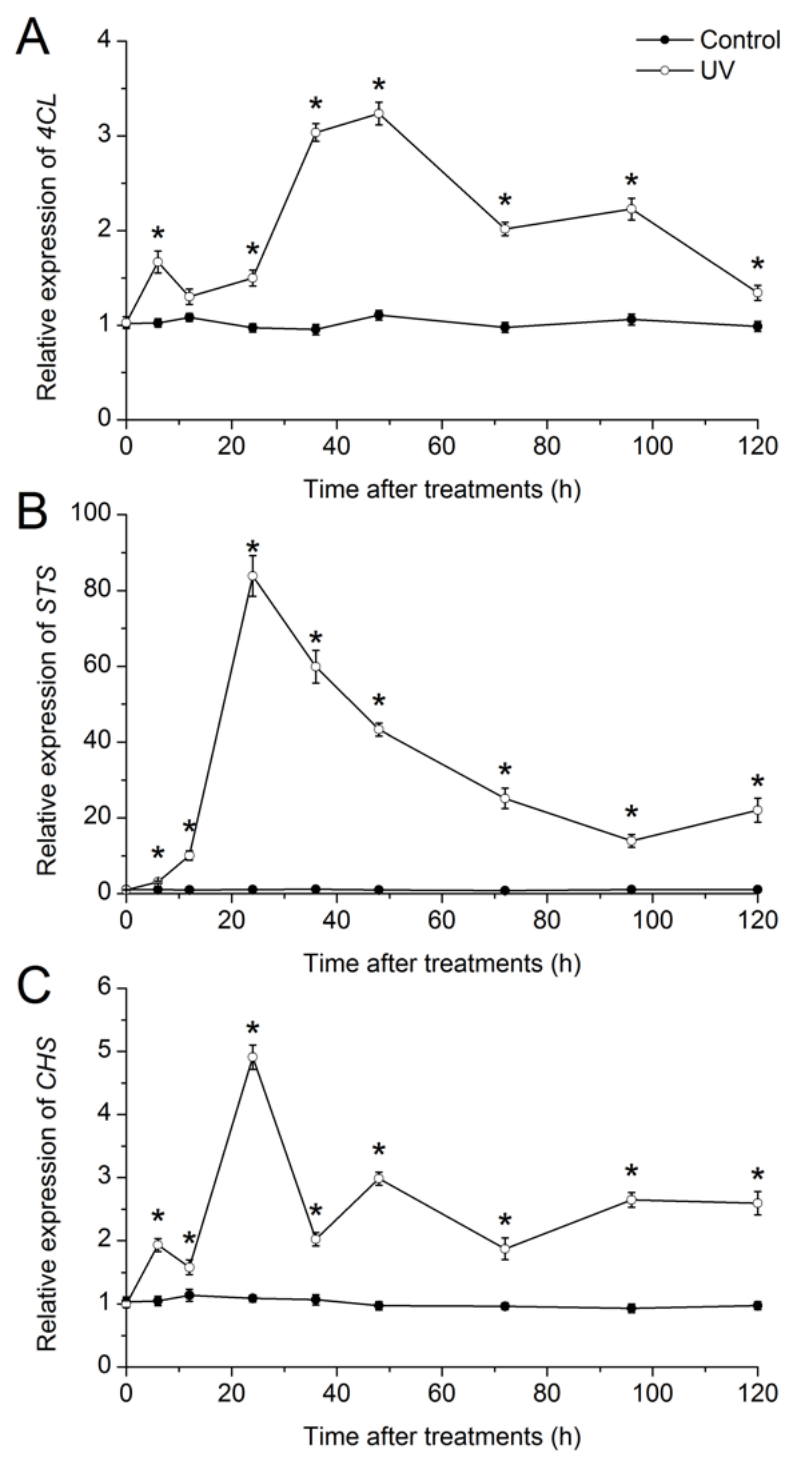

FIGURE 8

Changes in relative expression of $4 C L$ (A), STS (B) and CHS (C) in Vitis vinifera L. cv. Cabernet Sauvignon calli induced by UV-C irradiation over a $120 \mathrm{~h}$ time course. Calli at day 18 were irradiated by UV-C (output $10 \mathrm{~W} / \mathrm{m}^{2}$ ) for 20 min (total exposure dosage was $12 \mathrm{KJ} / \mathrm{m}^{2}$ ). Calli without $\mathrm{UV}-\mathrm{C}$ irradiation were used as the control group. Values are means $\pm \mathrm{SE}(\mathrm{n}=3)$. (*) indicates the statistically significant difference (Student's $t$-test, $p<0.05$ ) between the UV-C and control groups at each time point.

of véraison, and $20 \mathrm{~min} \mathrm{UV}-\mathrm{C}$ irradiation was optimal for the induction of calli. The relative expression of genes associated with the branching point of the stilbene and flavonoid pathway (4CL, STS and $C H S$ ) was significantly up-regulated by UV-C elicitation, in parallel with stilbene and flavonoid production. UV-C irradiation can be used as an efficient method to produce stilbene-enriched grapes, which may be a good source for healthy winemaking.

\section{LITERATURE CITED}

Adrian, M., Jeandet, P., Douillet-Breuil, A.C., Tesson, L. \& Bessis, R., 2000. Stilbene content of mature Vitis vinifera berries in response to UV-C elicitation. J. Agric. Food Chem. 48, 6103-6105. 
Bavaresco, L., Vezzulli, S., Civardi, S., Gatti, M., Battilani, P., Pietri, A \& Ferrari, F., 2008. Effect of lime-induced leaf chlorosis on ochratoxin A, trans-resveratrol, and $\varepsilon$-viniferin production in grapevine (Vitis vinifera L.) berries infected by Aspergillus carbonarius. J. Agric. Food Chem. 56, 20852089

Belhadj, A., Saigne, C., Telef, N., Cluzet, S., Bouscaut, J., Corio-Costet, M.F. \& Mérillon, J.M., 2006. Methyl jasmonate induces defense responses in grapevine and triggers protection against Erysiphe necator. J. Agric Food Chem. 54, 9119-9125.

Boss, P.K., Davies, C. \& Robinson, S.P., 1996. Analysis of the expression of anthocyanin pathway genes in developing Vitis vinifera L. cv Shiraz grape berries and the implications for pathway regulation. Plant Physiol. 111, 1059-1066.

Cantos, E., Espín, J.C., Fernández, M.J., Oliva, J. \& Tomás-Barberán, F.A., 2003. Postharvest UV-C-irradiated grapes as a potential source for producing stilbene-enriched red wines. J. Agric. Food Chem. 51, 1208-1214.

Cantos, E., García-Viguera, C., De Pascual-Teresa, S. \& Tomás-Berberán, F.A., 2000. Effect of postharvest ultraviolet irradiation on resveratrol and other phenolics of cv. Napoleon table grapes. J. Agric. Food Chem. 48, 4606-4612.

Crupi, P., Pichierri, A., Basile, T. \& Antonacci, D., 2013. Postharves stilbenes and flavonoids enrichment of table grape cv Redglobe (Vitis vinifera $\mathrm{L}$.) as affected by interactive UV-C exposure and storage conditions Food Chem. 141, 802-808.

Dai, R., Ge, H., Howard, S. \& Qiu, W.P., 2012. Transcriptional expression of stilbene synthase genes are regulated developmentally and differentially in response to powdery mildew in Norton and Cabernet Sauvignon grapevine. Plant Sci. 197, 70-76.

Delaunois, B., Cordelier, S., Conreux, A., Clément, C. \& Jeandet, P., 2009. Molecular engineering of resveratrol in plants. Plant Biotechnol. J. 7, 2-12.

Dixon, R.A. \& Paiva, N.L., 1995. Stress-induced phenylpropanoid metabolism. Plant Cell 7, 1085-1097.

Douillet-Breuil, A.C., Jeandet, P., Adrian, M. \& Bessis, N., 1999. Changes in the phytoalexin content of various Vitis spp. in response to ultraviolet $\mathrm{C}$ elicitation. J. Agric. Food Chem. 47, 4456-4461.

Fornara, V., Onelli, E., Sparvoli, F., Rossoni, M., Aina, R., Marino, G. \& Citterio, S., 2008. Localization of stilbene synthase in Vitis vinifera L. during berry development. Protoplasma 233, 83-93.

Frankel, E.N., Waterhouse, A.L. \& Teissedre, P.L., 1995. Principal phenolic phytochemicals in selected California wines and their antioxidant activity in inhibiting oxidation of human low-density lipoproteins. J. Agric. Food Chem. 43, 890-894.

Gamborg, O.L., Murashige, T., Thorpe, T.A. \& Vasil I.K., 1976. Plant tissue culture media. In Vitro Cell. Dev. Biol., Plant 12, 473-478.

Gatto, P., Vrhovsek, U., Muth, J., Segala, C., Romualdi, C., Fontana, P., Pruefer, D., Stefanini, M., Moser, C., Mattivi, F. \& Velasco, R., 2008 Ripening and genotype control stilbene accumulation in healthy grapes. J. Agric. Food Chem. 56, 11773-11785.

Ghanim, H., Sia, C.L., Abuaysheh, S., Korzeniewski, K., Patnaik, P., Marumganti, A., Chaudhuri, A. \& Dandona, P., 2010. An antiinflammatory and reactive oxygen species suppressive effects of an extract of Polygonum cuspidatum containing resveratrol. J. Clin. Endocrinol. Metab. 95, E1-E8.

González-Barrio, R., Beltrán, D., Cantos, E., Gil, M.I., Espín, J.C. \& Tomás-Barberán, F.A., 2006. Comparison of ozone and UV-C treatments on the postharvest stilbenoid monomer, dimer, and trimer induction in var. 'Superior' white table grapes. J. Agric. Food Chem. 54, 4222-4228.

González-Barrio, R., Vidal-Guevara, M.L., Tomás-Barberán, F.A. \& Espín, J.C., 2009. Preparation of a resveratrol-enriched grape juice based on ultraviolet C-treated berries. Innov. Food Sci. Emerg. Technol. 10, 374-382.
Guerrero, R.F., Puertas, B., Fernández, M.I., Palma, M. \& Cantos-Villar, E., 2010. Induction of stilbenes in grapes by UV-C: Comparison of different subspecies of Vitis. Innov. Food Sci. Emerg. Technol. 11, 231-238.

Hain, R., Bieseler, B., Kindl, H., Schröder, G. \& Stöcker, R., 1990. Expression of a stilbene synthase gene in Nicotiana tabacum results in synthesis of the phytoalexin resveratrol. Plant Mol. Biol. 15, 325-335.

Hanhineva, K., Kokko, H., Siljanen, H., Rogachev, I., Aharoni, A. \& Kärenlampi, S.O., 2009. Stilbene synthase gene transfer caused alterations in the phenylpropanoid metabolism of transgenic strawberry (Fragaria $\times$ ananassa). J. Exp. Bot. 60, 2093-2106

Hüsken, A., Baumert, A., Milkowski, C., Becker, H.C., Strack, D. \& Möllers, C., 2005. Resveratrol glucoside (piceid) synthesis in seeds of transgenic oilseed rape (Brassica napus L.). Theor. Appl. Genet. 111, 1553-1562.

Jang, M.S., Cai, E.N., Udeani, G.O., Slowing, K.V., Thomas, C.F., Beecher, C.W.W., Fong, H.H.S., Farnsworth, N.R., Kinghorn, A.D. \& Mehta, R.G., 1997. Cancer chemopreventive activity of resveratrol, a natural product derived from grapes. Science 275, 218-220.

Jeandet, P., Bessis, R. \& Gautheron, B., 1991. The production of resveratrol (3,5,4'-trihydroxystilbene) by grape berries in different developmental stages. Am. J. Enol. Vitic. 42, 41-46.

Jeandet, P., Clément, C. \& Courot, E., 2014b. Resveratrol production at large scale using plant cell suspensions. Eng. Life Sci. 14, 622-632.

Jeandet, P., Clément, C., Courot, E. \& Cordelier, S., 2013. Modulation of phytoalexin biosynthesis in engineered plants for disease resistance. Int. J. Mol. Sci. 14, 14136-14170.

Jeandet, P., Delaunois, B., Aziz, A., Donnez, D., Vasserot, Y., Cordelier, S. \& Courot, E., 2012. Metabolic engineering of plants and yeast for the production of the biologically active hydroxystilbene, resveratrol. J. Biomed. Biotechnol. Article 579089.

Jeandet, P., Delaunois, B., Conreux, A., Donnez, D., Nuzzo, V., Cordelier, S., Clément, C. \& Courot, E., 2010. Biosynthesis, metabolism, molecular engineering, and biological functions of stilbene phytoalexins in plants. BioFactors 36, 331-341.

Jeandet, P., Douillet-Breuil, A.C., Bessis, R., Debord, S., Sbaghi, M. \& Adrian, M., 2002. Phytoalexins from the Vitaceae: Biosynthesis, phytoalexin gene expression in transgenic plants, antifungal activity, and metabolism. J Agric. Food Chem. 50, 2731-2741.

Jeandet, P., Hébrard, C., Deville, M.A., Cordelier, S., Dorey, S., Aziz, A. \& Crouzet, J., 2014a. Deciphering the role of phytoalexins in plantmicroorganism interactions and human health. Molecules 19, 18033-18056.

Jeandet, P., Sbaghi, M. \& Bessis, R., 1992. The production of resveratrol $\left(3,5,4^{\prime}\right.$ - trihydroxystilbene) by grapevine in vitro cultures, and its application to screening for grey mould resistance. J. Wine Res. 3, 47-57.

Langcake, P. \& Pryce, R.J., 1977. The production of resveratrol and the viniferins by grapevines in response to ultraviolet irradiation. Phytochem. $16,1193-1196$

Li, X.D., Wu, B.H., Wang, L.J. \& Li, S.H., 2006. Extractable amounts of trans-resveratrol in seed and berry skin in Vitis evaluated at the germplasm level. J. Agric. Food Chem., 54, 8804-8811.

Liu, W., Liu, C.Y., Yang, C.X., Wang, L.J. \& Li, S.H., 2010. Effect of grape genotype and tissue type on callus growth and production of resveratrols and their piceids after UV-C irradiation. Food Chem. 122, 475-481.

Livak, K.J. \& Schmittgen, T.D., 2001. Analysis of relative gene expression data using real-time quantitative PCR and the $2^{-\Delta \Delta C T}$ method. Methods 25 , 402-408.

Logemann, E., Tavernaro, A., Schulz, W.G., Somssich, I.E. \& Hahlbrock, K., 2000. UV light selectively coinduces supply pathways from primary metabolism and flavonoid secondary product formation in parsley. Proc. Natl. Acad. Sci. U.S.A. 97, 1903-1907. 
López-Hernández, J., Paseiro-Losada, P., Sanches-Silva, A.T. \& LageYusty, M.A., 2007. Study of the changes of trans-resveratrol caused by ultraviolet light and determination of trans- and cis-resveratrol in Spanish white wines. Eur. Food Res. Technol. 225, 789-796.

Morales, M., Bru, R., García-Carmona, F., Barceló, A.R. \& Pedreño, M.A., 1998. Effect of dimethyl- $\beta$-cyclodextrins on resveratrol metabolism in Gamay grapevine cell cultures before and after inoculation with Xylophilus ampelinus. Plant Cell Tissue Organ. Cult. 53, 179-187.

Pastrana-Bonilla, E., Akoh, C.C., Sellappan, S. \& Krewer, G., 2003. Phenolic content and antioxidant capacity of Muscadine grapes. J. Agric. Food Chem. 51, 5497-5503.

Pezet, R., Gindro, K., Viret, O. \& Spring, J.L., 2004. Glycosylation and oxidative dimerization of resveratrol are respectively associated to sensitivity and resistance of grapevine cultivars to downy mildew. Physiol. Mol. Plant Pathol. 65, 297-303.

Pezet, R., Perret, C., Jean-Denis, J.B., Tabacchi, R., Gindro, K. \& Viret, O., 2003. $\delta$-viniferin, a resveratrol dehydrodimer: One of the major stilbenes synthesized by stressed grapevine leaves. J. Agric. Food Chem. 51, 54885492 .

Soleas, G.J., Diamandis, E.P. \& Goldberg, D.M., 1997. Resveratrol: A molecule whose time has come and gone. Clin. Biochem. 30, 91-113.

Tassoni, A., Fornale, S., Franceschetti, M., Musiani, F., Michael, A.J., Perry, B. \& Bagni, N., 2005. Jasmonates and Na-orthovanadate promote resveratrol production in Vitis vinifera cv. Barbera cell cultures. New Phytol. 166, 895-905.

Versari, A., Parpinello, G.P., Tornielli, G.B., Ferrarini, R. \& Giulivo, C., 2001. Stilbene compounds and stilbene synthase expression during ripening, wilting and UV treatment in grape cv. Corvina. J. Agric. Food Chem. 49, 5531-5536.
Vitrac, X., Bornet, A., Vanderlinde, R., Valls, J., Richard, T., Delaunay, J.C., Mérillon, J.M. \& Teissédre, P.L., 2005. Determination of stilbenes ( $\delta$-viniferin, trans-astringin, trans-piceid, cis- and trans-resveratrol, $\varepsilon$-viniferin) in Brazilian wines. J. Agric. Food Chem. 53, 5664-5669.

Wallerath, T., Deckert, G., Ternes, T., Anderson, H., Li, H., Witte, K. \& Förstermann, U., 2002. Resveratrol, a polyphenolic phytoalexin present in red wine, enhances expression and activity of endothelial nitric oxide synthase. Circulation 106, 1652-1658.

Wang, L.J., Ma, L., Xi, H.F., Duan, W., Wang, J.F. \& Li, S.H., 2013. Individual and combined effects of $\mathrm{CaCl}_{2}$ and $\mathrm{UV}-\mathrm{C}$ on the biosynthesis of resveratrols in grape leaves and berry skins. J. Agric. Food Chem. 61, 7135-7141.

Wang, W., Tang, K., Yang, H.R., Wen, P.F., Zhang, P., Wang, H.L. \& Huang, W.D., 2010. Distribution of resveratrol and stilbene synthase in young grape plants (Vitis vinifera L. cv. Cabernet Sauvignon) and the effect of UV-C on its accumulation. Plant Physiol. Biochem. 48, 142-152.

Waterhouse, A.L. \& Lamuela-Raventos, R.M., 1994. The occurrence of piceid, a stilbene glucoside in grape berries. Phytochem. 37, 571-573.

Waters, D.L.E., Holton, T.A., Ableff, E.M., Lee, L.S. \& Henry, R.J., 2005. cDNA microarray analysis of developing grape (Vitis vinifera cv. Shiraz) berry skin. Funct. Integr. Genomics 5, 40-58.

Winkel-Shirley, B., 2001. Flavonoid biosynthesis. A colorful model for genetics, biochemistry, cell biology, and biotechnology. Plant Physiol. 126, 485-493.

Wolfe, K., Wu, X.Z. \& Liu, R.H., 2003. Antioxidant activity of apple peels. J. Agric. Food Chem. 51, 609-614.

Zinser, C., Jungblut, T., Heller, W., Seidlitz, H.K., Schnitzle, J.P., Ernst, D. $\&$ Sandermann, H., 2000. The effect of ozone in Scots pine (Pinus sylvestris L.) gene expression, biochemical changes and interactions with UV-B radiation. Plant Cell Environ. 23, 975-982. 